Budianto Tedjasuskmana, Lindrawati, Marini Purwanto, Dian Purnama Sari

Vol. 3 No 2, Agustus 2021

ISSN 2657-0203

e-ISSN 2686-0244

\title{
ANALISIS PEMBELAJARAN AKUNTANSI SECARA DARING DI SMAK “X”
}

\author{
Budianto Tedjasuskmana ${ }^{1}$, Lindrawati ${ }^{2}$, Marini Purwanto ${ }^{3}$, Dian Purnama Sari ${ }^{4}$ \\ Universitas Katolik Widya Mandala Surabaya \\ Program Studi Akuntansi, Fakultas Bisnis \\ budianto@ukwms.ac.id ${ }^{1}$, lindrawati@ukwms.ac.id ${ }^{2}$, marini@ukwma.ac.id ${ }^{3}$, \\ dian-ps@ukwms.ac.id ${ }^{4}$
}

\begin{abstract}
Abstrak
Kegiatan pembelajaran daring adalah kegiatan proses belajar mengajar yang dilakukan pada saat ini diatur oleh kebijakan Pemerintah dalam rangka menghindari wabah COVID-19 yang sedang melanda pada masyarakat di Indonesia dan di seluruh dunia. Namun, pembelajaran daring sendiri masih menuai pro dan kontra karena dirasa belum mampu diserap secara penuh oleh para siswa didik. Kegiatan pengabdian masyarakat ini dilakukan dengan memberikan pembelajaran daring di sebuah SMAK melalui media google meet serta memberikan kuis melalui media google form. Setelah seluruh proses dilaksanakan, para siswa mengisi kuisioner sehingga dapat mengukur efektivitas pembelajaran daring yang dilakukan. Hasil kegiatan pengabdian masyarakat ini menunjukkan bahwa siswa memang lebih merasa mudah memahami materi melalui sistem pembelajaran tatap muka, meskipun dalam pembelajaran daring lebih dari $30 \%$ siswa masih dapat memahami materi dengan baik. Para siswa masih membutuhkan motivasi belajar sehingga guru mungkin dapat memberikan materi dengan lebih banyak variasi.
\end{abstract}

Kata kunci-Pembelajaran Daring, Akuntansi, Motivasi Belajar

\begin{abstract}
Online learning activities are teaching and learning process activities that are currently being regulated by Government policies in order to avoid the COVID-19 outbreak that is currently hitting people in Indonesia and around the world. However, online learning itself still reaps pros and cons because students feel that they are not fully absorbed by students. This community service activity is carried out by providing online learning at a high school through google meet media as well as providing quizzes via google form media. After the whole process was carried out, the students filled out a questionnaire so that they could measure the effectiveness of the online learning that was being carried out. The results of this community service activity show that students really find it easier to understand the material through the face-to-face learning system, although in online learning more than 30\% of students can still understand the material well. Students still need motivation to learn so that teachers may be able to provide material with more variety.
\end{abstract}

Keywords-Effectivity, Online Learning, Accounting, Motivation to Learn 


\section{PENDAHULUAN}

Masa pandemi COVID-19 telah mengubah hampir pada semua tatanan kehidupan dalam masyarakat, termasuk dalam dunia Pendidikan. Semua tingkatan jenjang pendidikan menyelenggarakan sistem pembelajaran, yang awalnya dilakukan secara tatap muka di kelas, berubah drastis menjadi pembelajaran dalam jaringan yang dikenal sebagai istilah daring. Kesiapan material maupun kesiapan psikologis sempat menjadi masalah dalam pembelajaran daring. Perubahan situasi dan kondisi yang mendadak ini tidak jarang membuat banyak siswa tidak mampu menyerap materi belajar secara mendalam, termasuk pelajaran akuntansi. Padahal, para siswa SMA khususnya bagi siswa kelas XII, yang hendak melanjutkan studinya ke perguruan tinggi tentu membutuhkan sistem pembelajaran yang efektif. Khususnya bagi siswa yang akan melanjutkan pendidikannya ke jurusan akuntansi, tentu hal ini akan merupakan kompetensi yang harus lebih ditekuni.

Permasalahan utama siswa SMA adalah lemahnya pemahaman dalam konsep dasar akuntansi yang menjadi kunci utama dalam mengerjakan secara teknis soal-soal akuntansi. Penguasaan dan pemahaman dalam konsep dasar, diharapkan dapat membantu dalam menyelesaikan soal-soal teknis Pemahaman dasar akuntansi yang kuat akan memudahkan pula dalam pengambilan keputusan khususnya apabila memilih kuliah di jurusan akuntansi atau sekurang-kurangnya dalam bidang pekerjaan yang berhubungan dengan akuntansi.

Kegiatan pengabdian masyarakat ini bertujuan untuk mengukur efektivitas pembelajaran daring, khususnya mata pelajaran akuntansi. Masa pandemi COVID-19 belum tentu akan berakhir dalam waktu singkat. Perlu adanya penyesuaian langkah pembaharuan agar supaya sistem pembelajaran yang ada telah sesuai sehingga para siswa dapat menyerap ilmu secara maksimal. Evaluasi terhadap sistem dan proses pembelajaran terhadap guru juga perlu untuk dilakukan.

\section{METODE}

Kegiatan pengabdian masyarakat ini dilakukan melalui beberapa tahapan kegiatan, yaitu:

1. Dosen yang melakukan pengabdian mayarakat berkoordinasi dengan guru akuntansi SMAK "X" untuk membahas materi yang selama ini telah diberikan dan materi apa yang sebaiknya diberikan saat kegiatan pengabdian masyarakat untuk mengukur efektivitas pembelajaran daring 
Budianto Tedjasuskmana, Lindrawati, Marini Purwanto, Dian Purnama Sari

Vol. 3 No 2, Agustus 2021

ISSN 2657-0203

e-ISSN 2686-0244

2. Pembelajaran daring oleh dosen akuntansi di SMAK " $X$ " yang dilakukan melalui media Google Meet. Pertemuan daring dilakukan 3x pertemuan online serta 1x pengerjaan latihan serta kuis.

3. Dosen yang melaksanakan pengabdian masyarakat melakukan evaluasi terhadap hasil latihan dan kuis yang dikerjakan oleh para siswa.

4. Para siswa diminta untuk mengisi kuisioner untuk menilai efektivitas pembelajaran daring yang dilakukan.

Kegiatan pengabdian masyarakat ini dilakukan di SMAK "X" dengan jumlah peserta yang terlibat adalah seluruh siswa kelas XII yang berjumlah 89 siswa.

\section{HASIL DAN PEMBAHASAN}

Kegiatan pengabdian masyarakat yang dilakukan dengan melakukan pembelajaran daring, diakhiri dengan pengisian kuisioner oleh para siswa yang mendapatkan pembelajaran daring. Total siswa yang mengikuti kegiatan adalah 89 siswa, namun dalam pengisian kuisioner ada 5 siswa yang tidak mengisi kuisioner tersebut, sehingga total 84 kuisioner yang dianalisis. Ada 10 indikator yang harus diisi oleh siswa dengan hasil yang disajikan berikut ini.

\section{Indikator Pertama: Pelajaran Akuntansi Sangat Menunjang Masa Depan}

Indikator pertama yang diukur adalah pemahaman dari para siswa bahwa mata pelajaran akuntansi merupakan salah satu pelajaran yang akan berguna bagi mereka di masa depan. Indikator ini juga merupakan hasil dari penjelasan yang pernah disampaikan pada saat pembelajaran daring melalui google meet mengenai profesi akuntan yang dapat para siswa capai apabila mereka mengambil jurusan akuntansi di perguruan tinggi. Hasil indikator pertama adalah sebagai berikut:

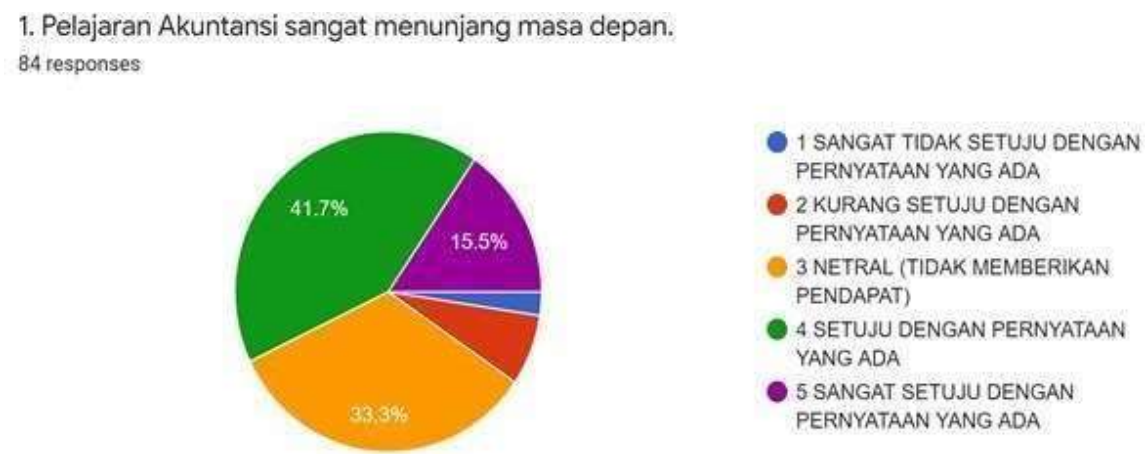

Indikator yang pertama menunjukkan bahwa 41,7\% siswa setuju bahwa pelajaran akuntansi dapat menunjang masa depan mereka, bahkan 15,5\% menyatakan sangat setuju. Meskipun ada 
Budianto Tedjasuskmana, Lindrawati, Marini Purwanto, Dian Purnama Sari

Vol. 3 No 2, Agustus 2021

ISSN 2657-0203

e-ISSN 2686-0244

9.5\% yang menyatakan kurang setuju dan sangat tidak setuju. Persentase ini menunjukkan bahwa para siswa sebenarnya yakin bahwa mata pelajaran akuntansi merupakan salah satu pelajaran yang menunjang masa depan mereka.

Indikator Kedua : Pelajaran Akuntansi dapat Mudah Dipahami dengan Sesama Kawan

\section{Melalui Media Sosial}

Indikator kedua yang diukur adalah kemudahan pemahaman pelajaran akuntansi secara bersama-sama dengan teman terutama melalui media sosial. Hasil indikator kedua adalah sebagai berikut:

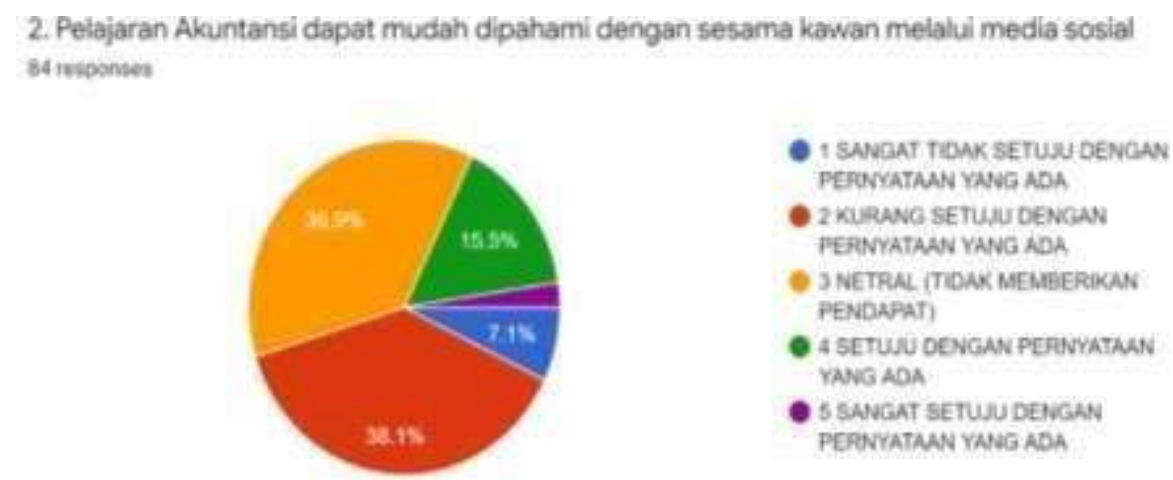

Indikator yang kedua menunjukkan bahwa 38,1\% siswa kurang setuju bahwa pelajaran akuntansi mudah dipahami bersama-sama dengan teman melalui media sosial, bahkan $7,1 \%$ menyatakan sangat tidak setuju. Meskipun ada $15.5 \%$ yang menyatakan setuju dan 2,4\% sangat setuju. Persentase ini menunjukkan bahwa para siswa sebenarnya lebih banyak yang merasa bahwa pelajaran akuntansi masih sulit dipahami meskipun Bersama-sama dengan teman mereka melalui media sosial.

\section{Indikator Ketiga: Pelajaran Akuntansi Lebih Mudah Dimengerti pada Tatap Muka di Kelas}

Indikator ketiga adalah mengukur kemudahan pembelajaran akuntansi secara tatap muka. Angkatan kelas XII masih sempat memperoleh pelajaran akuntansi secara tatap muka di kelas sebelumnya. Indikator ini memang kebalikan dari indikator kedua. Hasil indikator ketiga adalah sebagai berikut: 
3. Pelajaran Akuntansi lebih mudah dimengerti pada tatap muka dikelas. 84 responses
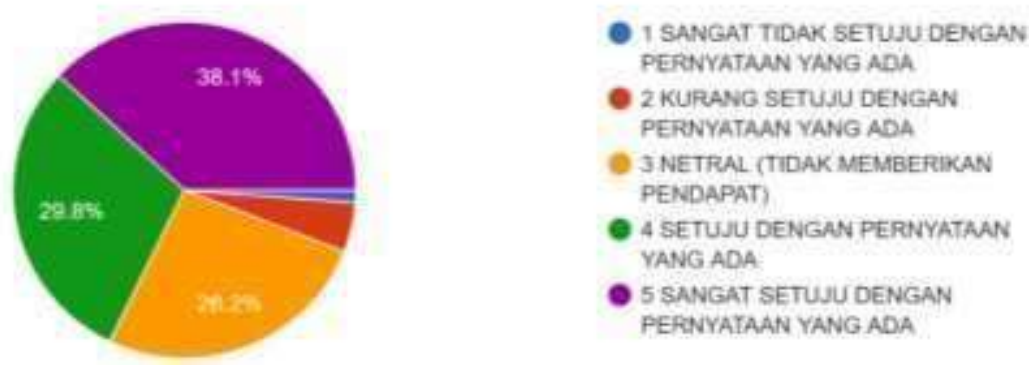

Indikator yang ketiga menunjukkan bahwa 29,8\% siswa setuju bahwa pelajaran akuntansi mudah dipahami saat pembelajaran tatap muka, bahkan $38,1 \%$ menyatakan sangat setuju. Hanya 5,9\% yang menyatakan kurang setuju dan sangat tidak setuju. Hasil ini selaras dengan hasil dari indikator yang kedua, bahwa para siswa lebih sulit memahami pelajaran akuntansi dengan teman melalui media sosial. Persentase ini menunjukkan bahwa para siswa sebenarnya secara mayoritas masih merasa lebih mudah memahami pelajaran akuntansi melalui pembelajaran tatap muka di kelas.

Indikator Keempat: Pelajaran Akuntansi Mandiri, Mudah Dipahami pada Tatap Maya (Online

\section{Learning)}

Indikator keempat adalah mengukur kemudahan pembelajaran akuntansi secara tatap maya. Indikator ini memang sejalan dengan indikator kedua. Hasil indikator keempat adalah sebagai berikut:

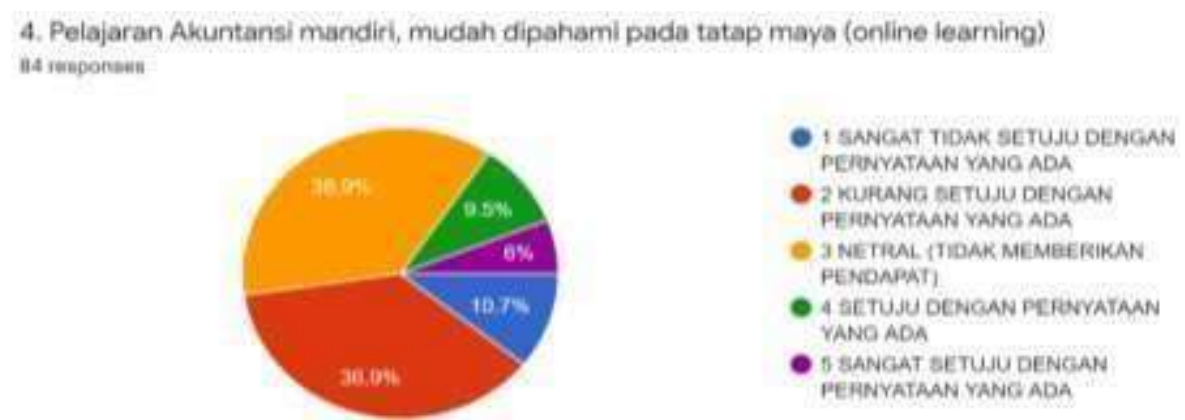

Indikator yang keempat menunjukkan bahwa 36,9\% siswa kurang setuju bahwa pelajaran akuntansi mudah dipahami pada tatap maya, bahkan 10,7\% menyatakan sangat tidak setuju. Meskipun ada 9,5\% yang menyatakan setuju dan 6\% sangat setuju. Hasil ini sejalan dengan indikator kedua dan berkebalikan dengan indikator ketiga. Persentase ini menunjukkan bahwa para siswa sebenarnya lebih banyak yang merasa bahwa pelajaran akuntansi masih sulit dipahami pada saat pembelajaran tatap maya. Indikator Kelima: Pelajaran Akuntansi Pada

\section{Usaha Jasa Lebih Mudah Dipahami}


Budianto Tedjasuskmana, Lindrawati, Marini Purwanto, Dian Purnama Sari

Vol. 3 No 2, Agustus 2021

ISSN 2657-0203

e-ISSN 2686-0244

Indikator kelima adalah kemudahan pembelajaran akuntansi pada topik usaha jasa. Pada indikator kelima mulai masuk ke topik akuntansi secara lebih khusus. Hasil indikator kelima adalah sebagai berikut:

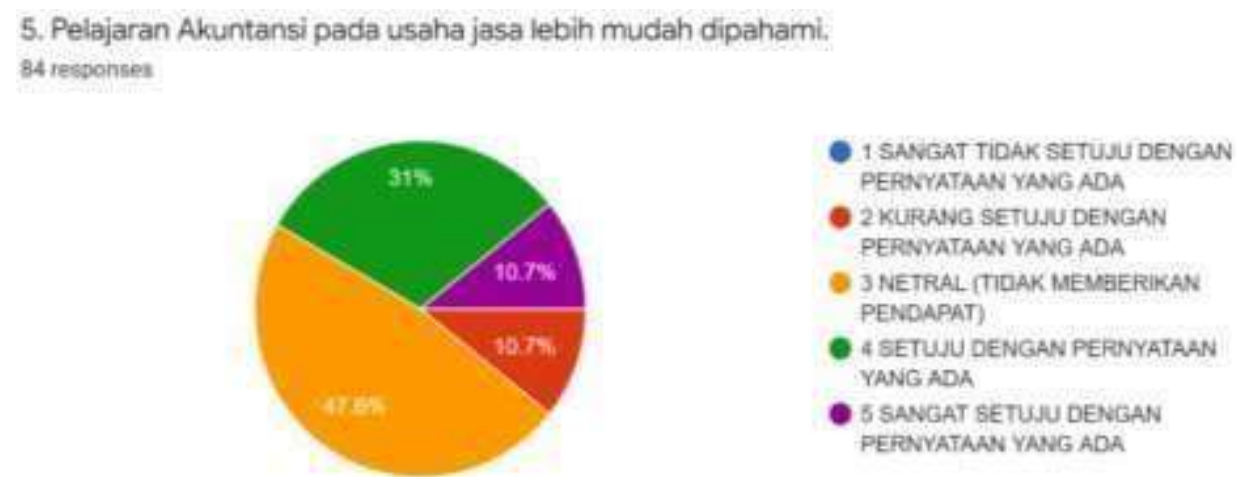

Indikator yang kelima menunjukkan bahwa $31 \%$ siswa setuju bahwa pelajaran akuntansi dengan topik usaha jasa mudah dipahami, bahkan 10,7\% menyatakan sangat setuju. Meskipun ada $10,7 \%$ menyatakan kurang setuju. Persentase ini menunjukkan bahwa topik akuntansi usaha jasa masih lebih mudah dipahami oleh mayoritas siswa.

\section{Indikator Keenam: Pelajaran Akuntansi Pada Usaha Dagang Lebih Mudah Dipahami}

Indikator keenam adalah kemudahan pembelajaran akuntansi pada topik usaha dagang. Hasil indikator keenam adalah sebagai berikut:

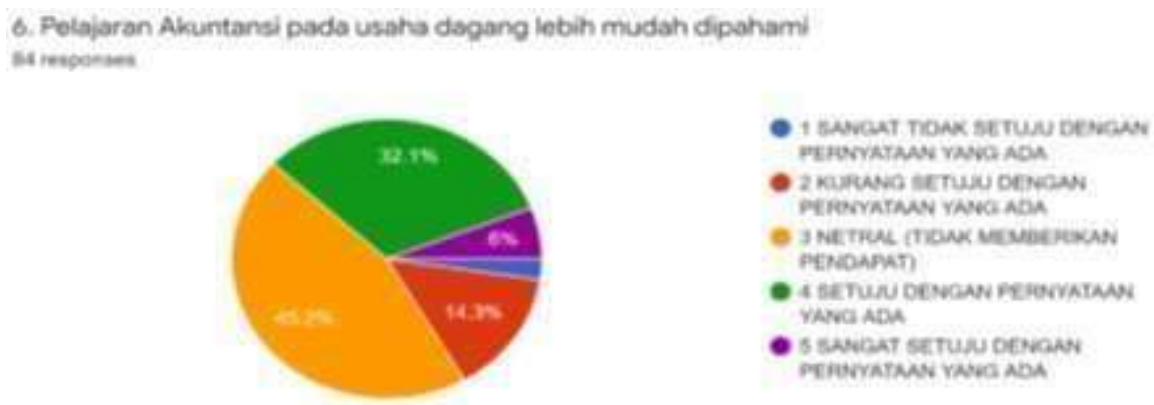

Indikator yang keenam menunjukkan bahwa 32,1\% siswa setuju bahwa pelajaran akuntansi dengan topik usaha dagang mudah dipahami, bahkan $6 \%$ menyatakan sangat setuju. Meskipun ada $14,3 \%$ menyatakan kurang setuju dan 2,4\% menyatakan sangat tidak setuju. Persentase ini senada dengan hasil indikator kelima yang menunjukkan bahwa topik akuntansi usaha dagang masih mudah dipahami oleh mayoritas siswa, meskipun total persentase setuju dan sangat setuju masih lebih rendah dibandingkan dengan indikator kelima. Total persentase kurang setuju dan sangat tidak setuju di indikator keenam juga lebih tinggi dibanding indikator kelima.

\section{Indikator Ketujuh: Materi Akuntansi pada saat Pengelompokkan Harta Utang Modal Sangat}

\section{$\underline{\text { Mudah }}$}

$\mathbf{6 8} \mid \mathrm{J}$ urnal B u a n a P en gabdian 
Budianto Tedjasuskmana, Lindrawati, Marini Purwanto, Dian Purnama Sari

Vol. 3 No 2, Agustus 2021

ISSN 2657-0203

e-ISSN 2686-0244

Indikator ketujuh adalah kemudahan materi akuntansi pada saat pengelompokkan harta utang modal.

Hasil indikator ketujuh adalah sebagai berikut:

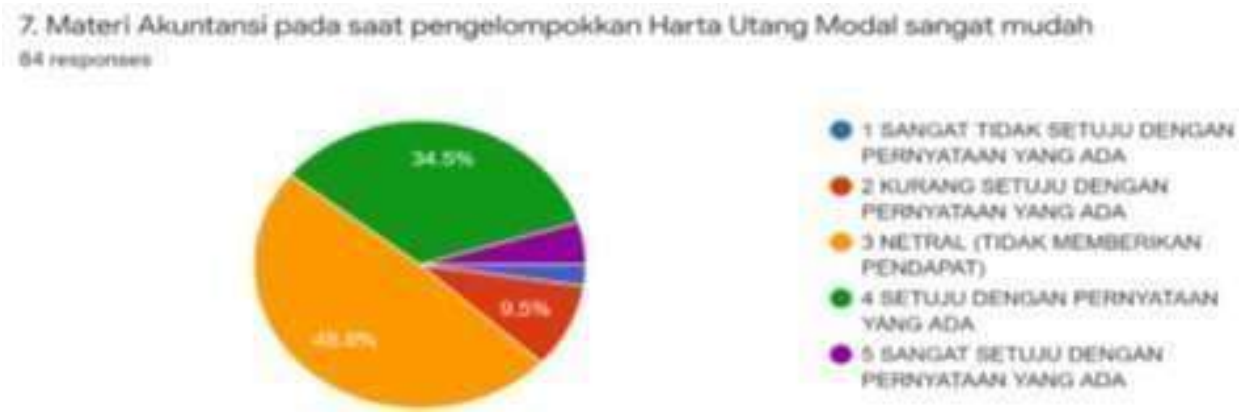

Indikator yang ketujuh menunjukkan bahwa 34,5\% siswa setuju bahwa materi akuntansi bagian pengelompokkan harta utang modal mudah. Meskipun terdapat 9,5\% menyatakan kurang setuju. Persentase ini menunjukkan bahwa topik akuntansi materi akuntansi bagian pengelompokkan harta utang modal masih lebih mudah dipahami oleh mayoritas siswa.

Indikator Kedelapan: Materi Akuntansi pada saat Melakukan Penjurnalan dan Buku Besar Sangat Mudah

Indikator kedelapan adalah kemudahan materi akuntansi pada saat melakukan penjurnalan dan buku besar. Hasil indikator kedelapan adalah sebagai berikut:

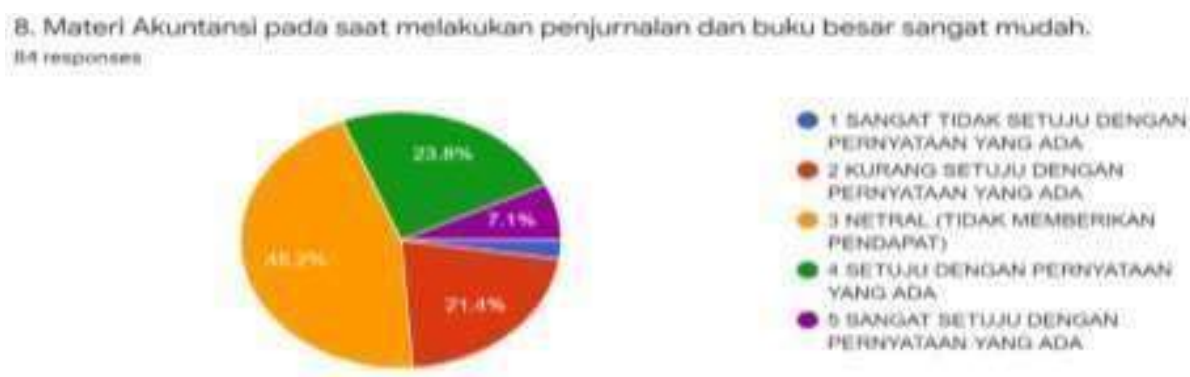

Indikator yang kedelapan menunjukkan bahwa 23,8\% siswa setuju bahwa materi akuntansi bagian penjurnalan dan buku besar mudah, bahkan 7,1\% sangat setuju. Meskipun terdapat Sebagian besar pula, 21,4\% menyatakan kurang setuju. Persentase ini menunjukkan bahwa topik akuntansi materi akuntansi bagian penjurnalan dan buku besar masih mudah dipahami oleh siswa, namun persentasenya memang lebih rendah dibandingkan dengan indikator ketujuh.

\section{Indikator Kesembilan: Materi Akuntansi Setelah Neraca Saldo Sulit Dipahami}

Indikator kesembilan adalah kesulitan materi akuntansi setelah neraca saldo. Indikator ini memang terbalik dengan indikator kelima sampai kedelapan yang menyatakan lebih mudah 69|Jurnal B u an a P engabdian 
atau sangat mudah. Hasil indikator kesembilan adalah sebagai berikut:
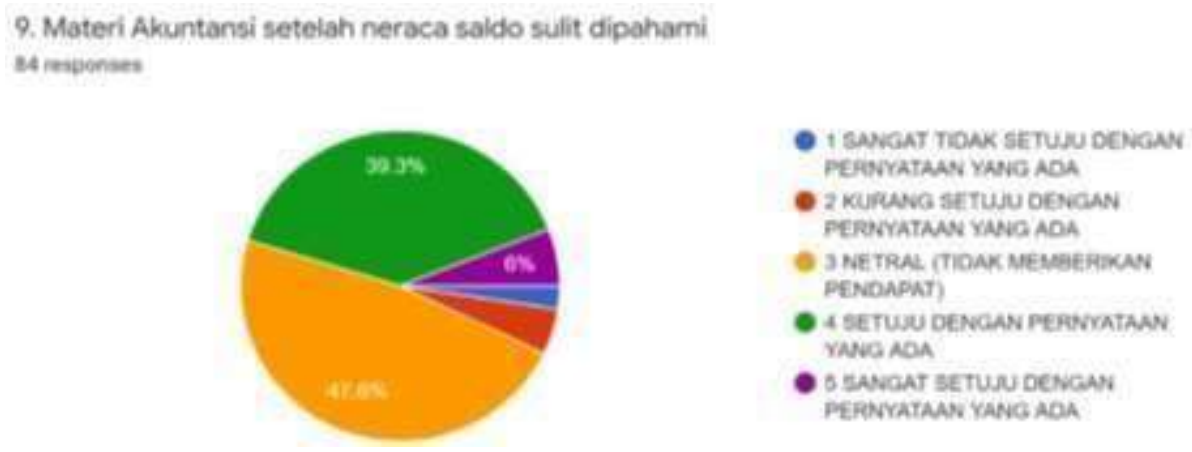

Indikator yang kesembilan menunjukkan bahwa 39,3\% siswa setuju bahwa materi akuntansi setelah neraca saldo sulit dipahami, bahkan 6\% sangat setuju. Terdapat 7,1\% yang merasa kurang setuju dan sangat tidak setuju dengan indikator ini. Persentase ini menunjukkan bahwa topik akuntansi materi akuntansi setelah neraca saldo masih sulit dipahami oleh mayoritas siswa.

\section{Indikator Kesepuluh: Soal Materi Akuntansi Tidak Mudah Ditafsirkan}

Indikator kesepuluh adalah kesulitan soal materi akuntansi untuk dipahami. Indikator ini memang terbalik dengan indikator kelima sampai kedelapan yang menyatakan lebih mudah atau sangat mudah. Hasil indikator kesepuluh adalah sebagai berikut:
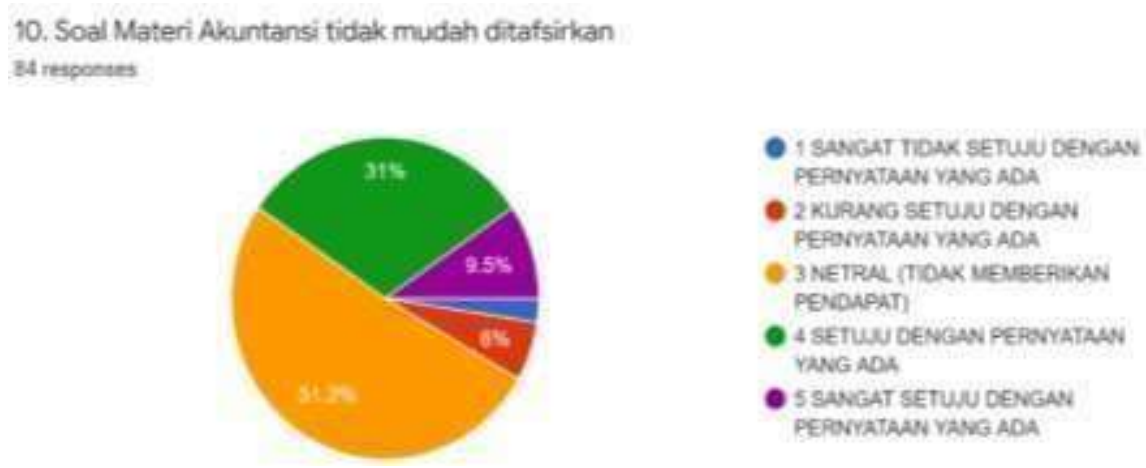

Indikator yang kesepuluh menunjukkan bahwa 31\% siswa setuju bahwa soal materi akuntansi masih sulit dipahami, bahkan 9,5\% sangat setuju. Terdapat $6 \%$ yang merasa kurang setuju dan2,3\% sangat tidak setuju dengan indikator ini. Persentase ini menunjukkan bahwa soal materi akuntansi masih sulit dipahami oleh mayoritas siswa.

\section{Pembahasan}

Pembelajaran dengan sistem daring menjadi salah solusi dalam masa pandemi ini Covid 
Budianto Tedjasuskmana, Lindrawati, Marini Purwanto, Dian Purnama Sari Vol. 3 No 2, Agustus 2021

ISSN 2657-0203

e-ISSN 2686-0244

19 saat ini. Pembelajaran daring juga merupakan sistem pembelajaran yang menggunakan jaringan internet dengan tingkat akses, koneksi, fleksibilitas, serta mampu meningkatkan lebih banyak interaksi dalam proses pembelajaran. Noveandini dan Wulandari (2010) mengungkapkan bahwa dengan menggunakan media jaringan internet serta teknologi informasi dapat merubah transformasi ilmu pembelajaran di kelas.

Pembelajaran daring juga sangat berpeluang untuk meningkatkan keberhasilan tujuan pembelajaran. Mengatasi permasalahan jarak dan waktu saat masa pandemi ini, pembelajaran dapat dilakukan dengan akses yang lebih luas dan dapat meningkatkan kemandirian belajar bagi siswa SMA. Wadah pembelajaran daring juga berpotensi untuk memperluas jaringan kelompok belajar siswa lebih aktif dan kolaboratif. Sekolah membuat kebijakan dalam pelaksanaan pembelajaran daring dengan memberikan keleluasaan kepada pengajar dalam menggunakan Flatform untuk mendukung seperti Google Classroom, Moddle, Zoom Meeting dan Google Meet. Namun perlu melihat tingkat efektivitas dari proses pembelajaran daring ini yang berorientasi pada keberhasilan tujuan pembelajaran yaitu hasil belajar mahasiswa. Sistem pembelajaran daring yang dilaksanakan oleh pengajar dikelola dengan baik agar meningkatkan keaktifan dan motivasi serta kemandirian belajar agar proses evaluasi hasil pembelajaran mahasiswa dapat tercapai dengan maksimal. Pembelajaran daring yang dilakukan dimasa pandemi Covid 19 memiliki banyak keterbatasan dalam penyerapan pembelajaran daring, hal ini disebabkan oleh banyak faktor yaitu kemandirian siswa yang belum memadai, hambatan kemampuan teknologi baik dari siswa karena adanya kemampuan ekonomi yang terbatas untuk pembiayaan kuota dalam menggunakan fasilitas teknologi berbayar (Putri dan Suparmi, 2020).

Kegiatan pengabdian masyarakat ini dilakukan untuk mengetahui efektivitas pembelajaran daring yang dilakukan pada mata pelajaran akuntansi. Hasil kegiatan pengabdian masyarakat ini menunjukkan bahwa mayoritas siswa menyadari bahwa pelajaran akuntansi merupakan salah satu pelajaran yang akan berguna bagi masa depan mereka. Mayoritas siswa juga mengakui bahwa pembelajaran akuntansi secara tatap muka di ruang kelas membuat proses memahami materi akuntansi menjadi lebih mudah. Indikator ketiga ini juga didukung dengan pernyataan di indikator kedua dan keempat di mana mayoritas siswa menyatakan bahwa pembelajaran akuntansi kurang dapat dipahami dengan pembelajaran daring maupun belajar bersama dengan teman melalui media sosial. Hasil ini menunjukkan bahwa memang 
Budianto Tedjasuskmana, Lindrawati, Marini Purwanto, Dian Purnama Sari

Vol. 3 No 2, Agustus 2021

ISSN 2657-0203

e-ISSN 2686-0244

mayoritas siswa merasa bahwa lebih mudah memahami materi akuntansi melalui pembelajaran tatap muka dibandingkan tatap maya.

Indikator kelima sampai indikator kesepuluh lebih menekankan pada pemahaman siswa mengenai materi dalam pembelajaran akuntansi. Tolak ukur dalam menyatakan suatu proses belajar mengajar dapat dikatakan berhasil adalah apabila daya serap terhadap mata pelajaran yang diajarkan mencapai prestasi tinggi (Usman, 2001). Hasil indikator 5 dan 6 menunjukkan bahwa mayoritas siswa dapat memahami materi baik perusahaan jasa maupun perusahaan dagang. Secara persentase, para siswa lebih banyak yang merasa lebih mudah memahami perusahaan jasa dibandingkan perusahaan dagang, meskipun tidak berbeda jauh. Untuk materi khusus persamaan dasar akuntansi (aset, liabilitas dan ekuitas) dan penjurnalan serta buku besar masih dapat dipahami sampai lebih dari 30\% siswa. Namun, untuk materi setelah neraca saldo, mayoritas menyatakan sulit untuk memahami. Lebih lanjut, soal materi akuntansi memang termasuk sulit untuk dipahami oleh sekitar 40\%. Hasil ini menunjukkan bahwa sejalan dengan indikator pertama sampai keempat, yang menunjukkan bahwa pada dasarnya, para siswa lebih mudah memahami materi akuntansi dengan media tatap muka, terutama materi yang tingkatan kesulitannya lebih tinggi.

Hasil kegiatan pengabdian masyarakat ini menunjukkan hasil bahwa pembelajaran daring memang berdampak pada kemudahan para siwa memahami materi. Pada hakikatnya, memang daya serap belajar erat kaitannya dengan prestasi belajar, karena semakin baik daya serap siswa dalam belajar maka siswa akan mendapatkan prestasi belajar yang semakin baik juga, sehingga faktor yang mempengaruhinya sama dengan faktor yang mempengaruhi prestasi belajar. Djamarah (2011) mengungkapkan pada dasarnya alat ukur daya serap sama dengan alat untuk penilaian keberhasilan belajar mengajar, sedangkan untuk mengukur dan mengevaluasi tingkat keberhasilan belajar dapat dilakukan melalui tes prestasi belajar (achievement test), termasuk salah satunya kuis dan latihan yang diberikan dalam kegiatan pengabdian masyarakat ini.

Hasil ini menunjukkan bahwa para siswa masih membutuhkan motivasi belajar yang tinggi. Sardiman (2012) menjelaskan bahwa motivasi dapat juga dikatakan sebagai serangkaian usaha untuk menyediakan kondisi- kondisi tertentu, sehingga seseorang mau dan ingin melakukan sesuatu, dan bila ia tidak suka, maka akan berusaha untuk meniadakan atau mengelakkan perasaan tidak suka itu. Sejalan dengan pendapat di atas menurut Adair (2007) 
Budianto Tedjasuskmana, Lindrawati, Marini Purwanto, Dian Purnama Sari

Vol. 3 No 2, Agustus 2021

ISSN 2657-0203

e-ISSN 2686-0244

motivasi adalah apa yang membuat orang melakukan sesuatu, tetapi arti yang lebih penting

dari kata ini adalah bahwa motivasi adalah apa yang membuat orang benar-benar berusaha dan mengeluarkan energi demi apa yang mereka lakukan. Definisi yang sederhana dari kata "motivasi' mungkin membuat orang mengerjakan apa yang harus dikerjakan dengan rela danbaik.

Motivasi belajar memang merupakan perasaan atau hasrat yang ada dalam setiap individu untuk melakukan sesuatu seacara sukarela atas kemauan sendiri atau dengan dorongan dari orang lain. Jika dikaitkan dengan pembelajaran akuntansi, siswa yang memiliki motivasi belajar yang tinggi terhadap mata pelajaran akuntansi, maka ia akan berusaha untuk mengejar prestasi belajar akuntansi. Di samping itu dengan adanya motivasi yang tinggi dalam belajar ekonomi, siswa akan menjadi rajin mengerjakan tugas yang diberikan oleh guru, dan siswa juga akan menjadi lebih rajin mempelajari pelajaran tersebut, baik di sekolah maupun di luar sekolah dengan senang hati dan tidak merasa terbebani . Dengan perasaan senang dan motivasi yang tinggi untuk mempelajari mata pelajaran akuntansi, maka siswa akan mudah menyerap mata pelajaran dengan mudah karena mata pelajaran akuntansi ini selain hitungan, juga membutuhkan pemahaman, bukan sekedar hafalan.

\section{KESIMPULAN DAN SARAN}

Hasil kegiatan pengabdian masyarakat ini menunjukkan bahwa para siswa merasa lebih mudah memahami pelajaran akuntansi melalui tatap muka dibandingkan daring. Namun, indikator yang berkaitan dengan materi khusus akuntansi juga menunjukkan bahwa mayoritas siswa cukup mudah memahami materi akuntansi, baik di perusahaan jasa maupun dagang, khususnya persamaan dasar akuntansi dan penjurnalan sampai buku besar. Materi yang berkaitan dengan neraca saldo lebih sulit dipahami oleh mayoritas siswa. Lebih lanjut soal materi akuntansi memang termasuk yang sulit dipahami karena memang soal dalam mata pelajaran akuntansi perlu pemahaman yang lebih dalam, karena selain hitungan, pelajaran akuntansi juga membutuhkan pemahaman mendalam. Para siswa masih membutuhkan motivasi belajar sehingga guru mungkin dapat memberikan materi dengan lebih banyak variasi.

Keterbatasan dalam hasil kegiatan pengabdian masyarakat ini adalah banyaknya jumlah siswa yang menjawab netral sehingga jawaban netral ini tidak dapat diinterpretasikan. Kegiatan 
Budianto Tedjasuskmana, Lindrawati, Marini Purwanto, Dian Purnama Sari

Vol. 3 No 2, Agustus 2021

ISSN 2657-0203

e-ISSN 2686-0244

ini juga tidak membahas secara mendalam masing-masing materi dalam pembelajaran akuntansi, misalnya kekhususan di perusahaan jasa dan perusahaan dagang. Saran untuk kegiatan pengabdian masyarakat selanjutnya dapat dibahas lebih lanjut mengenai perusahaan jasa dan dagang, yang merupakan materi utama untuk kurikulum pembelajaran kelas XII di SMA serta menjadi pembelajaran akuntansi dasar di perguruan tinggi.

\section{DAFTAR PUSTAKA}

Adair, J., 2007, Cara Menumbuhkan Pemimpin: 7 Prinsip Kunci, Jakarta: PT. Gramedia Pustaka Utama.

Djamarah, S. B., 2011, Psikologi Belajar, Jakarta: Rineka Cipta.

Noveandini, R., dan Wulandari, M. S., 2010, Pemanfaatan Media Pembelajaran secara Online (E-learning) Bagi Wanita Karir dalam Upaya Meningkatkan Efektivitas dan Fleksibilitas, Seminar Nasional Aplikasi Teknologi Informasi 2010 (SNATI 2010), Yogyakarta, June 19.

Putri, A. N., dan Suparmi, 2020, Efektivitas Pembelajaran Daring Program Studi Pendidikan Ekonomi, Jurnal Ecogen, No. 4, Vol. 3, 627-634, http://ejournal.unp.ac.id/students/index.php/pek/article/view/10618.

Sadirman, A. M., 2012, Interaksi dan Motivasi Belajar Mengajar, Jakarta: PT. Rajagrafindo.

Usman, M. U., 2001, Menjadi Guru Profesional, Bandung: Remaja Rosdakarya. 